J. Clin. Chem. Clin. Biochem.

Vol. 20, 1982, pp. $325-329$

\title{
N-Acetylglutamate Synthetase: Enzyme Assay in Human Liver ${ }^{1}$ )
}

\author{
By J. P. Colombo, S. Krähenbühl, C. Bachmann
}

Dept. of Clinical Chemistry, Inselspital, University of Berne, Berne Switzerland and

\section{P. Aeberhard}

Dept. of Visceral Surgery, Inselspital, University of Berne, Berne Switzerland

(Received September 1/November 25, 1981)

Summary: In the context of diagnostic procedures for congenital hyperammonaemias a method is described for the determination of $\mathrm{N}$-acetylglutamate synthetase in human liver tissue homogenates. The method uses $\left[{ }^{14} \mathrm{C}-\mathrm{U}\right]$ glutamate and acetyl $\mathrm{CoA}$ as substrates. The reaction product; $\mathrm{N}$-acetylglutamate is separated from the substrate $L$-glutamate by chromatography on Extrelut ${ }^{\circledR}$. In a subsequent step on ITLC-SG ready plates $\mathrm{N}$-acetylglutamate is separated from other labeled metabolites such as $\mathrm{Krebs}$ cycle intermediates. The recovery of $\mathrm{N}$-acetylglutamate was $97.8 \%$.

The precision within run and between days was $8.5 \%(\mathrm{CV})$ and $9.6 \%(\mathrm{CV})$ respectively. Reference values were established for adult human liver.

\section{N-Acetylglutamat Synthetase: Bestimmung des Enzyms in der menschlichen Leber}

Zusammenfassung: Es wird eine Methode zur Bestimmung der N-Acetylglutamat Synthetase in Homogenaten der menschlichen Leber beschrieben. Die Substrate sind $\left[{ }^{14} \mathrm{C}\right.$-U]Glutamat und Acetyl CoA. Das Reaktionsprodukt, $\mathrm{N}$-Acetylglutamat, wird von $L$-Glutamat durch Chromatographie auf Extrelut ${ }^{\circledR}{ }_{\text {abgetrennt. Im nachfolgenden Schritt }}$ wird N-Acetylglutamat mittels Dünnschichtchromatographie auf Silicagel-Folien von anderen markierten Metaboliten, namentlich aus dem Krebs-Zyklus, abgetrennt. Die Wiederfindung von N-Acetylglutamat beträgt 97,8\%.

Die Präzision in Serie und von Tag zu Tag zeigt einen Variạtionskoeffiżienten von 8,5\% resp. 9,6\%. Für die menschliche Erwachsenenleber wurden Referenzwerte aufgestellt.

\section{Introduction}

Congenital deficiencies have been described for every enzymatic step in the urea cycle $(1-3)$.

An enzyme which is not directly involved in the urea cycle, but plays a key role in its regulation, is $\mathrm{N}$-acetylglutamate synthetase (EC 2.3.1.1). It is activated by arginine and catalyses the synthesis of $\mathrm{N}$-acetylglutamate, a physiological, potent activator of carbamylphosphate synthetase $(4,5)$. It is present in mitochondria of liver and small intestine (6).

The synthesis of $\mathbf{N}$-acetylglutamate in mammals as well as the activation of $\mathrm{N}$-acetylglutamate synthetase by

1) Supported by the "Swiss National Science Foundation", Grant No. 3.551.79. arginine was first shown in rat and mice liver mitochondria by Shigesada \& Tatibana $(7,8)$.

Since no studies on human liver have been reported so farr, the enzyme was purified and characterized (9).

We recently had the opportunity to observe the first patient with $\mathrm{N}$-acetylglutamate synthetase deficiency (10). To confirm the diagnosis $\mathrm{N}$-acetylglutamate synthetase was determined in a liver biopsy specimen. The method presented here allows the determination of the enzyme in liver homogenate corresponding to about $30 \mathrm{mg}$ of tissue. It is based on the animal experiment of Shigesada \& Tatibana $(7,8,11)$.

The method uses $\left[{ }^{14} \mathrm{C}-\mathrm{U}\right] L$-glutamate and acetyl-CoA as substrates. 


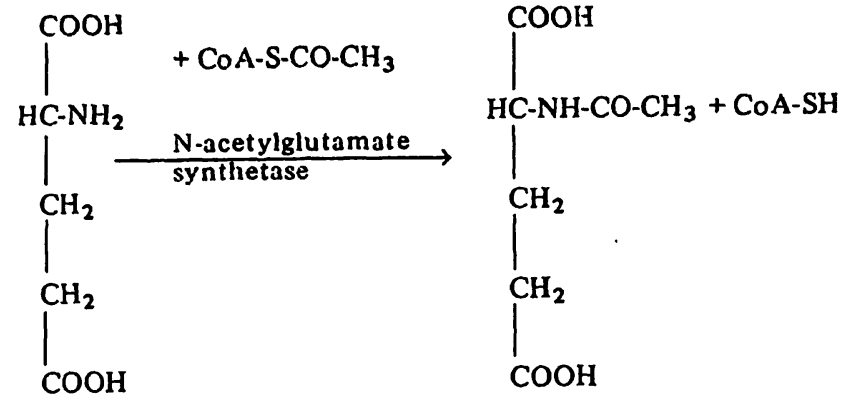

L-Glutamate $\quad$ N-Acetyl- $L$-glutamate

After incubation the reaction product $\mathrm{N}$-acetylglutamate is separated by two chromatographic steps from the remaining substrate and other labeled metabolites.

\section{Materials and Methods}

Chemicals

S-Acetyl-coenzyme-A (sodium salt) (Sigma, St. Louis, USA) (90-95\%),

$L$-Glutamic acid p.a. (Merck, Darmstadt, D),

$L-\left[{ }^{14} \mathrm{C}-\mathrm{U}\right]$ Glutamic acid (New England Nuclear, Boston, USA)

$\left(>8.3 \cdot 10^{9} \mathrm{~Bq} / \mathrm{mmol}, 2.5 \mathrm{ml}\right)$,

$\mathrm{N}$-Acetyl-L-glutamic acid (Fluka, Buchs, $\mathrm{CH}$ ),

$L$-Pyroglutamic acid (Sigma),

Hydrochloric acid (min. 37\%) (Merck),

Tris-(hydroxymethyl)-aminomethane (Merck),

Titriplex III (EDTA) p.a. (Merck),

Aquasol-2 (New England Nuclear),

Ammonia solution (min. 25\%) (Merck),

Bromphenol blue (water soluble) (Fluka),

$L$-Arginine monohydrochloride, puriss. p.a. (Fluka).

\section{Materials}

Extrelut $^{\circledR}$ (Merck),

ITLC-SG ready plates, $20 \times 20 \mathrm{~cm}$ (Gelman Instrument Company, Ann Arbor, USA),

Dowex 50 WX 8 (Serva, Heidelberg, D).

\section{Solutions}

Ammonia $0.02 \mathrm{~mol} / \mathrm{l}$,

Tris-buffer (250 mmol/l), EDTA ( $3 \mathrm{mmol} / \mathrm{l}), \mathrm{pH} 8.7$.

\section{Solvents for chromatography}

A: Methanol $(30 \mathrm{ml} / 1)$ and formic acid $(12 \mathrm{ml} / \mathrm{l})$ in chloroform,

B: Tert. amyl alcohol $(300 \mathrm{ml} / \mathrm{l})$ in chloroform,

C: Ether $(366 \mathrm{ml} / \mathrm{l})$ and formic acid $(24 \mathrm{ml} / \mathrm{l})$ in petroleum ether.

\section{Bromphenol blue}

$400 \mathrm{mg}$ bromphenol blue are dissolved in a mixture of $2 \mathrm{ml}$ ethanol and $2 \mathrm{ml} \mathrm{H} \mathrm{H}_{2} \mathrm{O}$. The $\mathrm{pH}$ is adjusted with $0.1 \mathrm{~mol} / 1$ $\mathrm{NaOH}$ to $6.5-7$. The solution is made up to $500 \mathrm{ml}$ with ethanol $960 \mathrm{ml} / \mathrm{l}$.

\section{Stop solution}

$160 \mathrm{mg} \mathrm{N}$-acetylglutamate are dissolved in $10 \mathrm{ml} \mathrm{H} \mathrm{H}_{2} \mathrm{O}$. Shortly before use this solution is mixed with $\mathrm{HCl} 5 \mathrm{~mol} / \mathrm{l}$ in equal parts.

\section{Substrate solution}

$L-\left[{ }^{14} \mathrm{C}\right.$-U]glutamic acid is purified on Dowex' $50 \mathrm{WX} 8\left(\mathrm{H}^{+}\right.$form $)$, $8.5 \mathrm{ml}$ fractions being eluted with $\mathrm{HCl}(2 \mathrm{~mol} / 1)$. The fractions with the highest radioactivity are pooled, dried and dissolved in an appropriate volume of bidistilled water to obtain a solution with $6.7 \cdot 10^{11} \mathrm{~Bq} / \mathrm{l}$. This solution is also used as a standard.

\section{L-glutamic acid/L-[ $\left[{ }^{14} \mathrm{C}\right.$-U]glutamic acid $(80 \mathrm{mmol} / \mathrm{ll})$}

$235.4 \mathrm{mg} L$-glutamic acid are dissolved in $10 \mathrm{ml}$ Tris-EDTAbuffer. One part of this solution $(125 \mu 1)$ is diluted $1: 2$ with $L-\left[{ }^{14}\right.$ Clglutamate immediately before use.

\section{L-arginine ( $8 \mathrm{mmol} / \mathrm{l})$}

$16.9 \mathrm{mg} L$-arginine $\mathrm{HCl}$ are dissolved in $10 \mathrm{ml}$ Trisis-EDTA -buffer̃.

\section{Acetyl-CoA/arginine solution}

$6 \mathrm{mg}$ of acetyl-CoA are weighed into Eppendorf tubes and $125 \mu \mathrm{l}$ Tris-EDTA-buffer and $125 \mu \mathrm{l}$ of arginine solution $(8 \mathrm{mmol} / \mathrm{l})$ are added.

\section{Procedure}

\section{Preparation of the homogenate}

Approx. $30 \mathrm{mg}$ of liver tissue are homogenized in $0.5 \mathrm{ml}$ of cold bidistilled water. The homogenate is sonicated 5 times $5 \mathrm{~s}$ at $40 \mathrm{~W}$ (Sonifier B 12 , Branson Sonic Power Comp., Danburg, USA) under efficient cooling in ice. $0.3 \mathrm{ml}$ are transferred to Eppendorf tubes and centrifuged for $10 \mathrm{~min}$ at $15000 \mathrm{~g}$.

Enzyme assay

\begin{tabular}{|c|c|c|}
\hline & $\begin{array}{l}\text { Sample } \\
\text { (ul) }\end{array}$ & $\begin{array}{l}\text { Blank } \\
\text { (ul) }\end{array}$ \\
\hline Glutamic acid $/ L-\left({ }^{14} \mathrm{C}\right.$-U]glutamic açid & 25 & 25 \\
\hline Acetyl-CoA with or without arginine & 25 & 25 \\
\hline Supernatant of sonicated liver homogenate & 50 & - \\
\hline Bidistilled water & - & 50 \\
\hline \multicolumn{3}{|l|}{ Incubation $20 \mathrm{~min}$ at $37^{\circ} \mathrm{C}$} \\
\hline Stop solution & 25 & 25 \\
\hline $\mathrm{HCl}, 0.1 \mathrm{~mol} / \mathrm{l}$ & 1000 & 1000 \\
\hline
\end{tabular}

$1 \mathrm{ml}$ of supernatant is applied on an Extrelut ${ }^{\circledR}$ column $(0.55 \mathrm{~g}$ Extrelut ${ }^{\circledR}$. column, $20 \mathrm{~cm} \times 1 \mathrm{~cm} \phi$ ).

The column is eluted with $50 \mathrm{ml}$ tert. amyl alcohol $(300 \mathrm{ml} / \mathrm{l})$ in chloroform (solvent B). The whole eluate is then evapoorated under nitrogen in a waterbath $\left(50^{\circ} \mathrm{C}\right)$. The residue is diluted in $100 \mu \mathrm{l}$ ammoniâ solution $(0.02 \mathrm{~mol} / \mathrm{l})$.

For further chromatographic separation $10 \mu \mathrm{l}$ of the dissolved residue are put on ITLC-SG plates. The plate is chromatographed in solvent A (front up to $20 \mathrm{~cm}$ ), then dried $10 \mathrm{~min}$ at $100^{\circ} \mathrm{C}$. For the second dimension chromatography is done over a $10 \mathrm{~cm}$ distance with solvent $C$ (approx. $10 \mathrm{~min}$ ) and then dried again. For detection the plate is sprayed with bromphenol blụe.

The $\mathrm{N}$-acetylglutamate spots $\left(\mathbf{R}_{\mathrm{f}}: 0.3 / 0.05\right)$ are cut out and placed in a counting vial. $5 \mathrm{ml}$ ammonia $(0.02 \mathrm{~mol} / \mathrm{l})$ are added, the vial shaken for $10 \mathrm{~min}$ and then $7 \mathrm{ml}$ aquasol- 2 is added. The solution 
is mixed and counted for $10 \mathrm{~min}$ in beta counter (Mod. Intertechnique, Paris, France).

The final concentration in the enzyme assay is:

Glutamic acid $20 \mathrm{mmol} / \mathrm{l}$,

Acetyl CoA $7 \mathrm{mmol} / \mathrm{l}$,

$L$-arginine $1 \mathrm{~mol} / \mathrm{l}$.

The enzyme activity is expressed in $\mathrm{mU} \cdot \mathrm{g}^{-1}$ liver tissue (wet weight), calculated according to the following formula:

$$
\mathrm{Bq} N A G \cdot \mathrm{nmol} g l u \cdot F_{c} \cdot F_{v} \cdot F_{t}
$$

Bq st

(NAG $=\mathrm{N}$-acetylglutamate, glu $=$ glutamic acid, $\mathrm{F}_{\mathrm{c}}=$ dilution factor for chromatography, $F_{v}=$ dilution factor for homogenate, $F_{t}=$ time factor, st = glutamic acid standard).

\section{Results}

Separation of substrates and products Column chromatography on Extrelut ${ }^{\circledR}$

We tried to separate $L$-glutamate, $\mathrm{N}$-acetylglutamate and $L$-pyroglutamate (arising from glutamate) on Extrelut ${ }^{\circledR}$ $0.5 \mathrm{ml}$ of a solution containing $1 \mathrm{mg}$ each of $L$-glutamate, $\mathrm{N}$-acetylglutamate and $L$-pyroglutamate was mixed with $0.5 \mathrm{ml} \mathrm{HCl}(1 \mathrm{~mol} / 1)$. The mixture was put on the Extrelut ${ }^{\circledR}$ column $\left(0.55 \mathrm{~g} \mathrm{Extrelut}^{\circledR}\right.$, column $20 \mathrm{~cm} \times 1 \mathrm{~cm} \phi)$. The column was eluted with $20 \mathrm{ml}$ of solvent $B$. The eluate was collected as a whole or in $5 \mathrm{ml}$ fractions which were then pooled. The whole eluate and the fractions were dried at $50^{\circ} \mathrm{C}$ under nitrogen and the residue taken up in $1 \mathrm{ml}$ ammonia ( 0.02 $\mathrm{mol} / \mathrm{l}) .10 \mu \mathrm{l}$ of these solutions were put on a cellulose thin layer plate (Merck). $\mathrm{N}$-acetylglutamate and $L$-pyroglutamate are eluted together completely. Glutamate however is retained. Examination of the different eluted fractions did not reveal any changes in separation compared to the batch elution.

\section{Thin layer chromätography}

If enzyme analysis is performed on tissue samples, interfering metabolites are to be expected. These must be separated from the substrate and product of the reaction. Particularly metabolites from the Krebs cycle which may interfere are not separated by the Extrelut ${ }^{\circledR}$ step. Therefore a thin layer chromatography step was added. After trying several systems, a fully satisfactory method was found using a 2 dimensional chromatography on ITLCSGready plates (usising solvents $A$ and $\mathbf{C}$ as indicated). Bromphenol blue was used for the detection. Figure 1 shows the separation of succinate, $L$-pyroglutamate, 2-oxoglutarate, $\mathrm{N}$-acetylglutamate, $L$-malate, $L$-citrate and $L$-glutamate.

On the basis of these findings it was possible to combine the Extrelut ${ }^{\circledR}$.step with a thin layer chromatography step. However, it was necessary to assess the recovery of the substances separated in these two steps, particularly of $\mathrm{N}$-acetylglutamate, the product of the enzyme reaction.

\section{Recovery of $N$-acetylglutamate}

These experiments had to be done with radioactive $\mathrm{N}$-acetylglutamate, since this final reaction product becomes labeled during its synthesis by $\mathrm{N}$-acetylglutamate synthetase. For this purpose $\left[{ }^{14} \mathrm{C}\right]$ $\mathrm{N}$-acetylglutamate was synthesized from $\left[{ }^{14} \mathrm{C}\right]$ $L$-glutamate according to a modification of the method of Noyori (12).

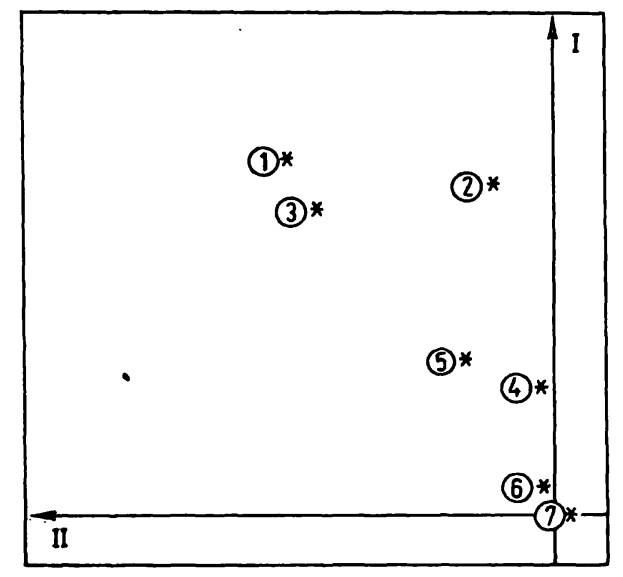

Fig. 1. 2-dimensional chromatography on ITLC-SG-ready plates.

$$
\begin{aligned}
& 1=\text { Succinate } \\
& 2=L \text {-Pyroglutamate } \\
& 3=2 \text {-Oxoglutarate } \\
& 4=\text { N-Acetylglutamate } \\
& 5=\text { Malate } \\
& 6=\text { Citrate } \\
& 7=L \text {-Glutamate }
\end{aligned}
$$

Solvents: 1: Methanol $(30 \mathrm{ml} / \mathrm{l})$ and formic acid $(12 \mathrm{ml} / \mathrm{l})$ in chloroform,

2: Ether $(36.6 \mathrm{ml} / \mathrm{l})$ and formic acid $(24 \mathrm{ml} / \mathrm{l})$ in petroleum ether.

* labeled compounds (see text).

$10 \mathrm{ml}$ of $\mathrm{HCl}$ solution $(0.5 \mathrm{~mol} / \mathrm{l})$ containing $\left[{ }^{14} \mathrm{C}\right] \mathrm{L}$ acetylglutamate $(83 \mathrm{kBq} / \mathrm{l})$ and $\mathrm{N}$-acetylglutamate $(1 \mathrm{~g} / \mathrm{l})$ was prepared. $1 \mathrm{ml}$ of this solution was put on 10 different Extrelut ${ }^{\circledR}$ columns and eluted as described above. The evaporated eluate was dissolved in ammonia $(0.02 \mathrm{~mol} / \mathrm{l}) .50 \mu \mathrm{l}$ were put in aquasol- 2 and the radioactivity counted. A further $20 \mu$ l of eluate were put on 10 different Extrelut ${ }^{\circledR}$ columns and eluted as described above. The evaporated eluate was dissolved in ammonia (0.02 mol/1). $50 \mu \mathrm{l}$ were put in aquasol-2 and the radioactivity counted. A further $20 \mu \mathrm{l}$ of eluate were put on the ITLC-SG-ready plates and chromatographed as described above. The $\mathrm{N}$-acetylglutamate spot was cut out and counted. The recovery after the Extrelut ${ }^{\circledR}$ step alone and after Extrelut ${ }^{\circledR}$ elution and ITLC-SG-chromatography was calculated in relation to the amount of $\left[{ }^{14} \mathrm{C}\right] \mathrm{N}$-acetylglutamate applied originally. 
The recovery for the Extrelut ${ }^{\circledR}$ step was $99.8 \%(\mathrm{CV}$ $0.5 \%, \mathrm{n}=10)$. For the Extrelut ${ }^{\circledR}$ system with the succeeding chromatographic step the recovery was $97.8 \%$ (CV $1.3 \%, \mathrm{n}=10$ ). These very high recoveries prove that the condition chosen for both steps are correct. These recoveries are higher than those described by Shigesada \& Tatibana in their system (13).

\section{Testing the enzyme assay by autoradiography}

$\left[{ }^{14} \mathrm{C}\right] \mathrm{N}$-acetylglutamate synthesized during incubation with liver homogenate can also be demonstrated using autoradiographic techniques. After the 2-dimensional chromatography on ITLS-SG ready plates these were placed directly on x-ray screen film (NS 2T, Kodak). After three days exposure the films were developed according to Swanstrom \& Shank (14). With this method activities up to $0.8 \mathrm{~Bq} / \mathrm{cm}^{2}$ can be detected.

Figure 1 shows that during the incubation new metabolites $(*)$ arise from the $\left[{ }^{14} \mathrm{C}\right]$ glutamate. These metabolites can easily' be separated by the thin layer step (ITLC-SG-system) from the substrate $L$-glutamate and the product $\mathrm{N}$-acetylglutamate.

Further investigations of the enzyme reaction

\section{Velocity and $\mathrm{pH}$}

The dependency of the velocity of the enzyme reaction on the amount of tissue used in the assay exhibited linearity up to a tissue content of $10 \mathrm{mg}$ per assay. With respect to the incubation time the reaction is linear up to 20 minutes.

The dependency of the reaction on the $\mathrm{pH}$ is shown in figure 2. With and without activation of the enzyme by arginine, the $\mathrm{pH}$ optimum is around 8.5. The activation due to arginine approx. doubles the activity. Further kinetic data were obtained with a purified human $\mathrm{N}$ -

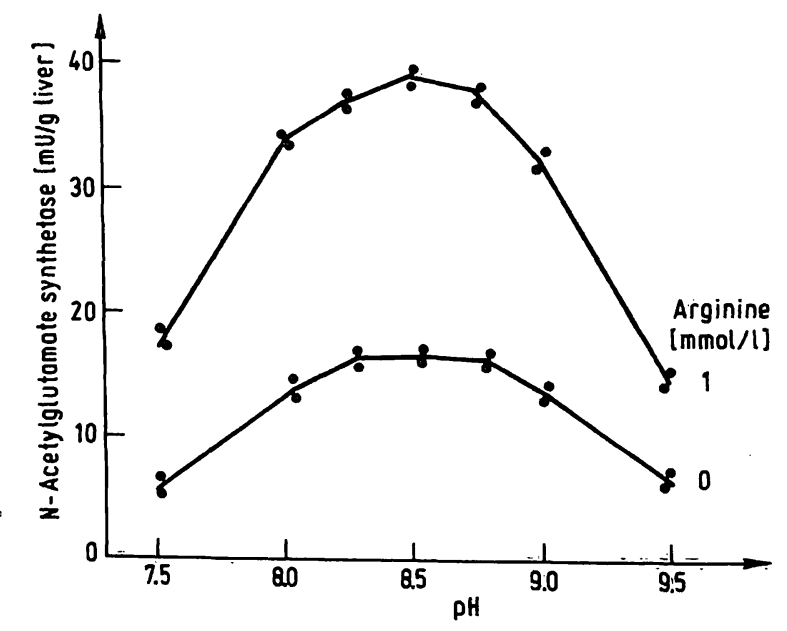

Fig. 2. N-Acetylglutamate synthetase. Dependency of the enzyme reaction on $\mathrm{pH}$. acetylglutamate synthetase preparation (9). The $K_{m}$ values for $L$-glutamic acid and acetyl CoA were 8.1 $\mathrm{mmol} / \mathrm{l}$ and $4.4 \mathrm{mmol} / \mathrm{l}$ respectively.

Within-run precision: Using the same tissue sample the within-run precision showed a coefficient of variation of $8.7 \%$ at a mean activity of $30.7 \mathrm{mU} / \mathrm{g}$ tissue $(n=6)$. This is in our opinion acceptable in view of the complexity of the enzyme assay.

Between day precision: The precision from day to day shows a coefficient of variation of $9.6 \%$ (tab. 1). The data further indicate that the storage of the liver homogenate at $-20^{\circ} \mathrm{C}$ during 5 days does not lead to a decrease of enzyme activity.

Tab. 1. N-Acetylglutamate synthetase: Between-day precision; Enzzyme activity measured on the same tissue sample at 5 subsequent days.

\begin{tabular}{lll}
\hline $\begin{array}{l}\text { Number } \\
\text { in days }\end{array}$ & $\begin{array}{l}\text { Time of storage } \\
\text { m-acetylglutamate synthetase } \\
\mathrm{mU} \cdot \overline{\mathrm{g}}^{-1} \text { wet weight }\end{array}$ \\
\hline 1 & 0 & 30.2 \\
2 & 1 & 33.5 \\
3 & 2 & 28.5 \\
4 & 3 & 27.5 \\
5 & 4 & 34.1 \\
& & $\overline{\mathrm{x}}=30.8, \mathrm{~s}=2.9, \mathrm{CV}=9.6 \%$ \\
\hline
\end{tabular}

\section{Reference values}

The amount of liver tissue (about $30 \mathrm{mg}$ ) necessary for the assay of $\mathrm{N}$-acetylglutamate synthetase usually cannot be obtained by a needle biopsy. Multiple needle biopsies embody the risk of haemornhage; thus it is preferable to perform a surgical biopsy. This becomes a limiting factor for establishing reference values. There: fore only a smäll number of liver specimens could be examined. Most of the control biopsies were taken from patients who were operated because of adenocarcinoma of the colon or rectum. Due to the limited number of assays, we could not account for sex differences. The age of the patients varied between 48 and 64 years. Preoperatively the patients had a standardized diet consisting of bouillon and tea for two days. A protein effect leading to an activation of $\mathrm{N}$-acetylglutamate synthetase which is known for other enzymes of the urea cycle can be avoided with this diet (15-17).

The determination of $\mathrm{N}$-acetylglutamate synthetase is merely used in the context of diagnoses of hyperammonaemia in the newborn and infant age. It was however not possible for ethical reasons to get reference samples in this age period. Table 2 showis the reference values with and without arginine per $g$ liver weight and per mg protein in 12 adult patients.

If this enzyme determination is done for diagnostic purposes an assay with and without arginine must be 
performed to guarantee a full activation of the enzyme and to detect also enzyme variants which may be activated in a different way.

Tab. 2. Reference values of $\mathbf{N}$-acetylglutamate synthetase in adult liver biopsies $(n=12)$.

\begin{tabular}{llcc}
\hline & & Median & Range \\
\hline Without & $\mathrm{mU} \cdot \mathrm{g}^{-1}$ liver & 14.5 & $5.6-33$ \\
arginine & $\mathrm{mU} \cdot \mathrm{g}^{-1}$ protein & 92 & $34-203$ \\
With & $\mathrm{mU} \cdot \mathrm{g}^{-1}$ liver & 35.7 & $22.5-52.1$ \\
arginine & $\mathrm{mU} \cdot \mathrm{g}^{-1}$ protein & 233 & $144-320$ \\
\hline
\end{tabular}

\section{Discussion}

The purpose of setting up a method for the determination of $\mathrm{N}$-acetylglutamate synthetase in human liver biopsy specimens is mainly aimed at the diagnosis of congenital hyperammonaemias $(1-3)$.

$\mathrm{N}$-acetylglutamate generated in the $\mathrm{N}$-acetylglutamate synthetase reaction $(18,19)$ holds a key position in regulation of urea synthesis. As shown recently, the deficiency of $\mathrm{N}$-acetylglutamate synthetase may have been the cause of hyperammonaemia of unknown origin in newborn and small infants (10).

The methods for the determination of most urea cycle enzymes are not easy to perform. This is also the case for $\mathrm{N}$-acetylglutamate synthetase.

The method described uses $\left[{ }^{14} \mathrm{C}\right.$-U]labeled glutamate and acetyl CoA as substrates. The substrate concentrations used are based on kinetic studies with the purified human enzyme (9). It is composed of three steps: the incubation step and two separation steps. After incubation the reaction product $\mathbf{N}$-acetylglutamate is separated

\section{References}

1. Shih, V. E. (1978) in: The metabolic basis of inherited disease. (Stanbury, J. B., Wyngaardèn, J. B. \& Fredricksen, D. S., eds.) McGràw-Hill, New-York, pp. 362-386.

2. Colombo, J. P. (1971) Monographs in Paediatrics, Vol. 1, Karger Basel.

3. Farriaux, J. P. (1978) in: Le cycle de l'urée et ses anomaliès. Doin, Paris.

4. Grisolia, S. \& Cohen, P. P. (1953) J. Biol. Chem. 204, 753

5. McGivan, J. D., Bradford, N. M. \& Mendes-Murao, J. (1976) Biochem. J. 154, 415-421.

6. Uchiyama, C., Mori, M. \& Tatibana, M. ${ }^{\prime}(1981)$ J. Biochem. 89, 1777-1786.

7. Shigesada, K. \& Tatibana, M. (1971) Biochem. Biophys. Res. Comm. 44, 117-124.

8. Shigesada, K. \& Tatibana, M. (1978) Eur. J. Biochem. 84, $285-291$.

9. Bachmann, C., Krähenbühl, S. \& Colombo, J. P. (1982) Biochem. J., in press.

10. Bachmann, C., Krähenbühl, S., Colombo, J. P., Schubiger, G. Jaggi, K. H. \& Tönz, O. (1981) New Engl. J. Med. 304, 543.

11. Tatibana, M., Shigesada, K. \& Mori, M. (1976) in: The Urea Cycle. (Grisolia, S., Baguena, R. \& Mayor, F., eds.) J. Wiley and Sons, New. York, p. 95-195.

12. Noyori, G., Hindemoto, K. \& Watanabe, T. (1966) Chemical Abstracts 6.5, $13828 \mathrm{~b}$. from the substrate $L$-glutamate by chromatography on Extrelut ${ }^{\circledR}$ instead of Dowex 50-X8, as proposed by Shigesada \& Tatibana (8). Many side reactions are to be expected in crude liver biopsy homogenates. Therefore a newly introduced thin layer chromatography step is used to separate the reaction product from the labeled metabolites, particularly from the Krebs cycle intermediates. Although some of these could be avoided by using glutamate labeled in position 1 , this compound is only available as the $D . L$-racemate and with a considerably lower specific activity.

Working with sonicated liver homogenates the activity of aminoacylase (EC 3.5.1.14) could be a disturbing factor, leading to the breakdown of $\mathrm{N}$-acetylglutamate. According to Reglero et al. (20) there is practically no activity of this enzyme in the mitochondria, whereas it is easily measurable in the cytosol (21). However aminoacylase exhibits its $\mathrm{pH}$ optimum at $\mathrm{pH} 7$ (22). At $\mathrm{pH} 8.5$ used in the $\mathrm{N}$-acetylglutamate synthetase reaction the activity of the aminoacylase is approximately half the maximal rate (23). The final concentration of $\mathrm{N}$-acetylglutamate in the assay described is below $0.1 \mathrm{mmol} / 1$, whereas the $K_{\mathrm{m}}$ value of aminoacylase for $\mathrm{N}$-acetylglutamate is about $10 \mathrm{mmol} / \mathrm{l}(20)$. On the basis of these observations we think that the interference of aminoacylase, if present at all, is certainly minimal.

The method has a good within-run and between day precision as well as a good recovery. The enzyme activity is linear with time and protein content over a large range.

Its usefullness has been proven in the diagnosis of the first case of $\mathrm{N}$-acetylglutamate synthetase deficiency (10).
13. Shigesada, K. \& Tatibana, M. (1971) Biochem. Biophys. Res. Comm. 44, 117-124.

14. Swanstrom, R. \& Shank, P. R. (1978) Anal. Biochem. 86, $184-192$.

15. Shigesada, K., Aoyagi, K. \& Tatibana, M. (1978) Eur. J. Biochem. 85, 385-391.

16. Schimke, R. T. (1962) J. Biol. Chem. 237, 459.

17. Aebi, H. (1976) in: The Urea Cycle. (Grisolia, S., Baguena, R. $\dot{\&}$ Mayor, F., eds.) John Wiley and Sons, New York, pp. 275-296.

18. Tatibana, M. \& Shigesada, K. (1976) in: The Urea Cycle. (Grisolia, S., Baguena, R. \& Mayor, F., eds.) John Wiley and Sons, New York, p. 301-313.

19. Colombo, J. P. (1981) Enzyme 26, 225-232.

20. Reglero, A., Rivas, J., Mendelson, J., Wallace, R. \& Grisolia, S. (1977) FEBS Letters 81, 13-17.

21. Kim, S., Pain, W. U. \& Cohen, P. P. (1972) Proc. Nat. Acad. Sci. USA 69, 3530-3533.

22. Birnbaum, S. M. (1963) Meth. Enzymol. 6, 589.

23. Maskova, H., Barth, T., Jrovsky, B. \& Rychlik, J. (1973) Collection Czechosiov. Chem. Commun. 35, 943-947.

Prof. J. P. Colombo, M.D. Chemisches Zentrallabor der Universitätskliniken Inselspital CH-3010 Bern / Schweiz 